\title{
Análise comparativa de protocolos para extração de DNA de galinhas caipiras em relação à eficiência, facilidade da extração e custo
}

Aylton Bartholazzi Junior ${ }^{1}$, Djalma Sthel Torres ${ }^{1}$, Celia Raquel Quirino ${ }^{2 *}$, Thiago Corrêa Silva $^{1}$, Aline Pacheco ${ }^{3}$, Steveen Ribeiro Leal ${ }^{1}$, Dayana Rangel Falcão ${ }^{1}$, Aparecida De Fátima Madella-Oliveira ${ }^{4}$

${ }^{1}$ Aluno do Programa de Pós graduação em Ciência Animal da Universidade Estadual do Norte FluminenseDarcy Ribeiro - UENF,Campos dos Goytacazes-RJ, Brasil.junior_barth@hotmail.com

${ }^{2}$ Professor Associado do Laboratório de Reprodução e Melhoramento Genético Animal, Centro de Ciencias e Tecnologias Agropecuárias, Universidade Estadual do Norte FluminenseDarcy Ribeiro -UENF, Campos dos Goytacazes-RJ, Brasil.

3Professor Universidade Federal do Oeste de Pará. Santarém,PA. Brasil.

${ }^{4}$ Professor do Instituto Federal de Educação, Ciência e Tecnologia do Espírito Santo, Alegre, ES, Brasil

*Autor para correrspóndencia, E-mail: crq@uenf.br

RESUMO. Objetivou-se, com este trabalho testar três diferentes protocolos de extração de DNA, sendo dois para amostras de sangue e um para amostra de bulbo de penas, considerando a eficiência de extração, a quantidade, a qualidade do DNA extraído e o custo de extração. Foi coletado sangue de galinhas caipiras, através da punção da veia braquial e foram coletadas as penas da região peitoral em uma propriedade localizada no estado do Rio de Janeiro. Os protocolos testados foram: 1) Extração alcalina rápida pela coleta de sangue total; 2) Extração alcalina rápida do bulbo das penas da região peitoral e 3) Extração de DNA com kit comercial (Nucleo Spin ${ }^{\circledR}$ Tissue) para sangue em FTA Card (NucleoCard). Em todos os protocolos, após a extração, as amostras foram quantificadas e verificadas a concentração e a qualidade do DNA, através de espectrofotometria. Constatou-se que os protocolos 1 e 2 apresentaram bons resultados na quantidade do DNA extraído, porém contatou-se alta concentração de proteínas. No protocolo 3, observou-se baixa quantidade de DNA extraído, mas apresentando maior pureza. Todos os protocolos mostraram-se satisfatórios quanto à qualidade na amplificação, entretanto, pode-se concluir que os protocolos de extração alcalina (1 e 2)apresentaram maior facilidade de uso, rapidez na extração e menor custo quando comparados ao protocolo 3.

Palavra chaves: Aves, custos, DNA, PCR, sexagem.

Comparative analysis of DNA extraction protocols in free-range chickens with respect to efficiency, extraction facility and cost

\begin{abstract}
The objective of this paper was to test three different protocols for DNA extraction regarding the extraction efficiency, quantity, quality of DNA extracted and extraction cost. Animals were from a farm in Rio de Janeiro state. Feathers samples of free-range chickens were collected from pectoral and blood samples were collected from brachial vein. The protocols tested were: 1) Rapid alkaline extraction from total blood collect; 2) Rapid alkaline extraction from feathers bulb of pectoral; and 3) DNA extraction with blood commercial kit (Nucleo Spin ${ }^{\circledR}$ Tissue) in FTA Card (NucleoCard). After the extraction, samples were quantified e the concentration and quality of DNA were verified in all protocols, using spectrophotometry. The protocols 1 and 2 had good result in the amount of DNA extracted, but they had high concentration of proteins. Protocol 3 had low amount of DNA extracted, but it has high purity. All protocols had good results in relation to the quality of amplification, although, protocols 1 and 2 of alkaline extraction had more facility to use, higher speed in extraction and lower cost than protocol 3.
\end{abstract}

Key word: birds, costs, DNA, PCR, sexing. 


\section{Introdução}

Inicialmente, a avicultura caipira tinha a concepção de aves criadas com pouca tecnologia; porém, as aves criadas em sistema caipira, apresentam hoje, potencial de postura de 200 a 220 ovos ao ano e também aves especializadas para produção de carne (Santana Filho et al., 2012). Desta forma, a avicultura caipira tornou-se uma atividade economicamente viável para pequenas propriedades rurais que podem explorar este nicho de mercado com produtos diferenciados (Takahashi, 2003; Abreu et al., 2004) e maior lucratividade. Pesquisas que envolvem melhoramento genético, nutrição animal e ambiência têm sido realizadas com o objetivo de desenvolver aves mais adaptadas para melhoria dos índices produtivos da criação alternativa (Boelling et al., 2003; Savino et al., 2007).

A genética molecular é empregada como complementação aos métodos quantitativos tradicionalmente empregados. Através da seleção assistida por marcadores, é possível melhorar consideravelmente a eficiência dos programas de melhoramento. Alguns obstáculos da seleção fenotípica poderão ser parcialmente eliminados com o uso da informação molecular, resultando em uma seleção mais precoce e de custo mais baixos (Dekkers \& Hospital, 2002). Uma etapa importante no processo de identificação do genótipo dos indivíduos é a obtenção de DNA de boa qualidade. Existem vários protocolos que permitem a obtenção de DNA de diferentes tipos de amostras, porém, tem sido observado que há variações na qualidade e durabilidade da amostra obtida, e no tempo necessário para obtenção e nos custos (Fungaro \& Vieira, 2001; Coelho et al.,2004; Vieira et al., 2010).

As amostras de DNA são utilizadas para diversos tipos de estudos de análise do genoma, bem como para sexagem em aves onde não se observa dimorfismo sexual. Este trabalho tem como objetivo avaliar a quantidade e qualidade do DNA extraído, tempo para cada extração e o custo de três diferentes protocolos de extração de DNA, utilizando amostras de pena e sangue.

\section{Material e Métodos}

$\mathrm{O}$ projeto da pesquisa foi submetido $\mathrm{e}$ aprovado pelo Comitê de Ética de Uso de Animais da Universidade Estadual do Norte Fluminense sob o número117837.
Para a realização do trabalho foram utilizadas cinco galinhas caipiras jovens com idade entre cinco a 10 meses, mantidas em um sistema semi intensivo de criação. De cada animal foram coletadas amostras de sangue e penas visando testar os métodos de extração de DNA. As amostras de sangue foram coletadas através da punção da veia braquial. $O$ sangue foi armazenado em tubos com EDTA a $10 \%$ a temperatura de $4^{\circ} \mathrm{C}$ e uma pequena fração foi colocado em cartões FTA e mantidos a temperatura ambiente. As penas foram retiradas da região peitoral das aves. As coletas foram realizadas no período da manhã, horário de temperaturas mais amenas, visando minimizar o estresse das aves e manter o bem estar dos animais.

Foram realizados quatro protocolos de extração de DNA: 1) Extração alcalina rápida de DNA (utilizando sangue total); 2) Extração alcalina rápida de DNA (utilizando pena) e 3) Extração de DNA com Kit comercial NucleoSpin ${ }^{\circledR}$ Tissue/Macherey-Nagel ${ }^{\circledR}$ (utilizando sangue em FTA Card).

1. Extração alcalina rápida de DNA para amostra de sangue total (AR-S): foi utilizada a metodologia descrita por Coelho (2001). Foram colocados $100 \mu \mathrm{L}$ de sangue total em micro tubos de $1,5 \mathrm{~mL}$. Para lavagem adicionou-se $400 \mu \mathrm{L}$ de tampão $\mathrm{NE}\left(\mathrm{NaCl}\right.$, EDTA e $\mathrm{H}_{2} \mathrm{O}$ ultra pura), centrifugou-se por 5 minutos a $13.000 \mathrm{rpm}$ e retirou-se o sobrenadante, descartando-o. A lavagem foi repetida ainda por mais duas vezes. Após a lavagem acrescentou-se $50 \mu \mathrm{L}$ de solução de lise $(200 \mathrm{mM}$ de $\mathrm{NaOH})$, aquecendo-se em seguida $96{ }^{\circ} \mathrm{C}$ por 15 minutos.Em seguida foi realizada uma centrifugação a $13.000 \mathrm{rpm}$ por 5 minutos. Ao final, foram acrescentados $50 \mu \mathrm{L}$ de solução neutralizante (Tris $\mathrm{HCl}(1 \mathrm{M}), \quad \mathrm{HCl}$ (concentrado), qsp $\mathrm{H}_{2} \mathrm{O}$ ultra pura) com o objetivo de promover um $\mathrm{pH}$ próximo a $7 . \mathrm{O}$ armazenamento foi feito a $-4^{\circ} \mathrm{C}$.

2. Extração alcalina rápida de DNA para amostra de bulbo de pena (AR-P): os bulbos foram cortados e colocados em tubos de $600 \mu \mathrm{L}$. Foi adicionada inicialmente $250 \mu \mathrm{L}$ de solução de lise $(200 \mathrm{mM}$ de $\mathrm{NaOH})$, aquecendo-se a $96^{\circ} \mathrm{C}$ por $15 \mathrm{~min}$. Em seguida foi vortexado e centrifugado a $1200 \mathrm{rpm}$ por 10minutos, adicionando-se em seguida $250 \mu \mathrm{L}$ de solução neutralizante (Tris $\mathrm{HCl}(1 \mathrm{M}), \mathrm{HCl}$ (concentrado), qsp $\mathrm{H}_{2} \mathrm{O}$ ultra pura), com o objetivo de promover 
um $\mathrm{pH}$ próximo a 7. $\mathrm{O}$ armazenamento foi feito a $-4^{\circ} \mathrm{C}$.

3. Extração de DNA com Kit comercial NucleoSpin $^{\circledR}$ Tissue/Macherey-Nagel ${ }^{\circledR}$ (utilizando sangue em FTA Card) (FTA-S): as amostras foram processadas de acordo com o protocolo do fabricante. O cartão foi cortado, com o auxílio de um perfurador, em um disco de $1,2 \mathrm{~mm}$ e este colocado em um tubo eppendorf de $1,5 \mathrm{~mL}$. A primeira etapa foi a de pré-lise, onde foi adicionado $180 \mu \mathrm{L}$ de tampão T1. Em seguida, as amostras foram colocadas em banho maria por 10 minutos a $94^{\circ} \mathrm{C}$. Posteriormente foram adicionados $25 \mu \mathrm{L}$ da solução Proteinase $\mathrm{K}$, vortexado e incubado a $56^{\circ} \mathrm{C}$ por $1 \mathrm{~h}$ (vortexando ocasionalmente durante a incubação).A segunda etapa é a de lise onde foram adicionados $200 \mu \mathrm{L}$ do tampão $\mathrm{B} 3$, vortexando e incubando a $56^{\circ} \mathrm{C}$ por 10 minutos. $\mathrm{Na}$ próxima etapa, $210 \mu \mathrm{L}$ de etanol foram adicionados, centrifugando-se a $11.000 \mathrm{rpm}$ por 1minuto. Após esses procedimentos, foram feitas duas lavagens da membrana, na primeira lavagem foi adicionado $500 \mu \mathrm{L}$ do tampão $\mathrm{BW}$ e centrifugado por 1 minuto a $11.000 \mathrm{rpm}$ e na segunda foi adicionado $600 \mu \mathrm{L}$ do tampão B5 centrifugado a $11.000 \mathrm{rpm}$ por 1 minuto, fazendo uma nova centrifugação para remover o etanol residual. Na última etapa foi adicionado $100 \mu \mathrm{L}$ do tampão de eluição (BE), incubando a temperatura ambiente por 1 minuto e depois centrifugado a $11.000 \mathrm{rpm}$ por 1 minuto. Depois de removido o tampão, o disco foi aquecido a 56 ${ }^{\circ} \mathrm{C}$ por 10 minutos.

Após a elaboração dos três protocolos foi realizada a quantificação e avaliada a pureza do DNA genômico com espectrofometria utilizando o aparelho Nanodrop ${ }^{\circledR}$ (NanoDrop 2000c). O fator de conversão da absorbância em unidades de concentração foi $1 \mathrm{OD} 260=50 \mathrm{ng} / \mathrm{uL}$. A pureza foi constatada pela razão $A_{260} A_{280} \mathrm{e}$ $\mathrm{A}_{260} / \mathrm{A}_{230}$. A razão A260/280 deve apresentar um valor $\geq 1,8$, valor abaixo dessa estimativa considera-se que há contaminação por proteínas. E para a razão A260/230 esperam-se valores de $\geq 1,8$ valores abaixo dessa estimativa considera-se que há contaminação por sais/reagentes (Manual Nanodrop 2000c).

Com o objetivo de validar os resultados obtidos foi realizada a técnica de PCR destes produtos de extração dos três protocolos. As amostras das extrações pela técnica alcalina de sangue e pena foram diluídas na proporção de
1:50 vezes antes de serem realizadas as amplificações para adequar a concentração de DNA necessária para PCR.

As reações de PCR foram realizadas em volumes de $10 \mu \mathrm{L}$ por reação, contendo $2,5 \mu \mathrm{L}$ de amostra de DNA, tampão para PCR [10 mM Tris-HCl (pH 8.3) e $50 \mathrm{mMKCl}]$, dNTPs (200 $\mu \mathrm{M}$ de cada), $\mathrm{MgCl} 2(1,0-3,0 \mathrm{mM})$, Taq DNA polimerase (1U), um par de primers (20 p/mol de cada primer), água deionizada, e a amostra de DNA. O programa de PCR teve um passo inicial de desnaturação a $94^{\circ} \mathrm{C}$ por 5 minutos, seguido de uma segunda a etapa de 30 ciclos de amplificação, sendo que em cada ciclo foi estabelecido um tempo de 30 segundos para a desnaturação da dupla fita a $94^{\circ} \mathrm{C}, 30$ segundos para o anelamento dos primers $\left(52^{\circ} \mathrm{C}\right)$, e 60 segundos para a síntese da nova fita a $72{ }^{\circ} \mathrm{C}$. Após o último ciclo, as reações foram submetidas a um passo final de 5 minutos a $72{ }^{\circ} \mathrm{C}$ para a extensão final das fitas. Foi utilizado um par de primers alelo-específicos P2 (5'-TCTGCATCGCTAAATCCTTT-3') e P8 (5'- CTCCCAAGGATGAGRAAYTG-3'), utilizado para sexagem de aves, o primer P2 ligase ao gene $C H D-W$ enquanto o $\mathrm{P} 8$ liga-se ao CHD-Z.

A eletroforese foi realizada em gel de poliacrilamida a $8 \%(13,33 \mathrm{~mL}$ acrilamida, $10 \mathrm{~mL}$ TBE, $500 \mu \mathrm{L}$ de APS, $50 \mathrm{~mL}$ de água destilada, $33,3 \mu \mathrm{L}$ de TEMED).

Foi avaliado o custo dos protocolos para processar 50 amostras, considerando os preços dos reagentes e materiais utilizados. No entanto, o custo da mão-de-obra e o desgaste dos equipamentos não foram incluídos.

A análise de variância foi realizada pelo procedimento GLM (General Linear Models) do programa estatístico SAS® (SAS, 2009) e as médias comparadas pelo teste SNK.

\section{Resultados e Discussão}

$\mathrm{Na}$ Tabela 1 estão apresentadas as concentrações de DNA extraído das amostras de sangue e pena das cinco aves de acordo com o protocolo testado. Observa-se que para cada protocolo não houve diferenças $(\mathrm{P}>0,05)$ entre indivíduos. No entanto, entre protocolos nota-se que o método de extração alcalina rápida obteve maiores concentrações de DNA, sobretudo quando se utilizou bulbo de pena (protocolo 2). A utilização de penas ao invés de sangue para a obtenção de DNA genômico minimiza o estresse das aves e questões relacionadas à preservação da 
integridade do animal, além de ser um método rápido e fácil para obtenção de DNA de boa qualidade (Bello et al., 2001).

Neste experimento as menores concentrações de DNA foram obtidas utilizando cartão FTA no protocolo 3. Estes resultados seriam devido a etapa de purificação de DNA, que após as etapas de lavagem para retirar proteínas e reagentes utilizados, ocorre a perda de parte de DNA da amostra.

Tabela 1. Concentração e a média \pm desvio padrão $(\mathrm{ng} / \mu \mathrm{L})$ de DNA extraído pelos três diferentes protocolos utilizados nas cincos amostras coletadas de sangue e pena de galinhas caipiras

\begin{tabular}{lcccccc}
\hline Protocolos & \multicolumn{7}{c}{ Amostras } \\
\hline & 1 & 2 & 3 & 4 & 5 & Média \pm Desvio Padrão \\
1 (AR-S) & 580,9 & 447,9 & 299,2 & 641,6 & 90,7 & $412,06 \pm 222,76^{\mathrm{b}}$ \\
2 (AR-P) & 576,8 & 553,1 & 588,1 & 753,2 & 580,9 & $610,42 \pm 80,89^{\mathrm{a}}$ \\
3 (FTA-N) & 28,7 & 26,4 & 35,7 & 24,8 & 33,2 & $29,76 \pm 4,59^{\mathrm{c}}$
\end{tabular}

Médias na mesma coluna seguidas de letras diferentes diferem entre si $(\mathrm{P}<0,05)$ pelo teste SNK.

1 (AR-S): Extração Alcalina rápida de DNA utilizando sangue total; 2 (AR-P): Extração alcalina rápida de DNA utilizando pena; 3 (FTA-N): Extração de DNA com Kit comercial NucleoSpin® Tissue/Macherey-Nagel® (utilizando sangue em FTA Card).

Resultados contrários foram encontrados por Caldart et al. (2011) que compararam três protocolos de extração de DNA (FTA, Kit DNAzol e Sílica) utilizando amostras de sangue e leite de ovinos e caprinos, entretanto, estes autores realizaram uma centrifugação capturando $15 \mu \mathrm{L}$ do anel leucocitário (células nucleadas) e o protocolo utilizado para extração não apresentava etapas de lavagem, logo, a concentração de DNA seria maior que em protocolos com etapas de purificação. Os pesquisadores obtiveram maiores concentrações de DNA com o protocolo utilizando cartão FTA, tanto para sangue $(205,00$ ng) quanto para leite $(487,00 \mathrm{ng}$ ); porém o grau de impureza apresentado pelo FTA foi maior do que o observado neste trabalho (Tabela 2).

Para medir a concentração do DNA dupla fita, assim como de fita simples, utiliza-se o comprimento de onda $\lambda=260 \mathrm{~nm}$. Tal técnica é frequentemente utilizada para determinar a qualidade do DNA; a razão entre as leituras de $260 \mathrm{~nm}$ e $280 \mathrm{~nm}$ pode ser considerada um indicador de pureza da amostra. As amostras de DNA presentes com razão A260nm/A280nm que obtiverem valor aproximado de 1,8 a 2,0 podem ser consideradas livres de contaminantes (Manual Nanodrop2000c).

A pureza relacionada a proteínas observada por Caldart et al. (2011), para a extração de cartão FTA foi de 1,84 , inferior a deste trabalho que apresentou a razão A260/A280 média igual a 2,28 . A etapa de purificação do kit utilizado neste experimento apresentou maior eficiência comparado a kit utilizado por Caldart et al. (2011).

Silva et al. (2012) também encontraram valores superiores de DNA de bovino (2359 $\mathrm{ng}$ ) utilizando cartões FTA com o kit GenSolve $\left(\right.$ GenVault $^{\circledR}$ ), quando comparado aos encontrados neste experimento. Esta diferença na concentração, possivelmente foi influenciada pelo volume inicial da amostra para extração, onde estes autores utilizaram dois discos de FTA de $6 \mathrm{~mm}$, enquanto neste trabalho foi utilizado apenas um disco de $1,2 \mathrm{~mm}$. Outro fator discriminante entre os trabalhos foi o kit comercial de diferentes fabricantes utilizados.

As proteínas têm um cume de absorbância entre $280 \mathrm{~nm}$, assim sendo, uma contaminação com proteínas leva a uma diminuição da razão A260nm/A280nm.

Tabela 2. Relações de pureza (A260/280 e A260/230) de DNA extraído pelos três diferentes protocolos de galinhas caipiras.

\begin{tabular}{lcc}
\hline Protocolos & $\mathrm{A} 260 / 280$ & $\mathrm{~A} 260 / 230$ \\
\hline 1 (AR-S) & $1,30 \pm 0,07^{\mathrm{b}}$ & $0,31 \pm 0,06^{\mathrm{b}}$ \\
2 (AR-P) & $1,50 \pm 0,16^{\mathrm{b}}$ & $0,58 \pm 0,17^{\mathrm{b}}$ \\
3 (FTA-N) & $2,28 \pm 0,37^{\mathrm{a}}$ & $2,54 \pm 0,21^{\mathrm{a}}$ \\
\hline
\end{tabular}

Médias na mesma coluna seguidas de letras diferentes diferem entre si $(\mathrm{P}<0,05)$ pelo teste SNK.

1 (AR-S): Extração Alcalina rápida de DNA utilizando sangue total; 2 (AR-P): Extração alcalina rápida de DNA utilizando pena; 3 (FTA-N): Extração de DNA com Kit comercial NucleoSpin ${ }^{\circledR}$ Tissue/Macherey-Nagel ${ }^{\circledR}$ (utilizando sangue em FTA Card). 
De acordo com a tabela 2 pode-se verificar que nos protocolos 1 e $2^{\text {a }}$ relação A260/280 foi menor que no protocolo 3 podendo indicar maior concentração de proteínas contaminando estas amostras dos protocolos 1 e 2, cujo problema é decorrente da não utilização de etapas de purificação nestes protocolos rápidos e alcalinos, estando de acordo com trabalho publicado por Bartholazzi Junior et al. (2012).

Para a relação $\mathrm{A}_{260 /} \mathrm{A}_{230} \mathrm{OS}$ valores de absorbância maiores que 1,8 indicam DNA livre de contaminação por sais e reagentes. Observouse que o protocolo 3 apresentou DNA livre de contaminação por reagentes enquanto os protocolos 1 e 2 apresentaram DNA com contaminação por reagentes. Isto é esperado, pois os kits apresentam etapas de purificação e/ou lavagem que permite a retirada ou diminuição da concentração de proteínas, sais e reagentes utilizados durante a extração. Vieira et al. (2010) compararam três técnicas de extração em aves (FTA, fenol clororfómio e Alcalina rápida em penas), para posterior sexagem. Relataram que as três técnicas foram eficientes para extração e amplificação do DNA, mas a técnica utilizando cartões FTA conservou as amostras por muito mais tempo e apresentou melhor custo benefício.

Não foram encontrados trabalhos na literatura onde se apresentam valores de absorbância $\mathrm{A}_{260} / \mathrm{A}_{280}$ e $\mathrm{A}_{260 /} \mathrm{A}_{230}$ para amostras de sangue e penas de aves.

Após amplificação pela PCR e eletroforese em gel de agarose foi observado que todas as amostras e de todos os protocolos (alcalina rápida de sangue total; alcalina rápida de penas; e kit comercial NucleoSpin $^{\circledR}$ ) a amplificação do DNA foi positiva apresentando bandas em gel de 350 pares de base, confirmando assim o sucesso da extração. Os resultados obtidos são reforçados por análises de outros autores como Sharma et al. (2000) e Ali et al. (2002), ao utilizarem extração alcalina de sangue em codornas encontraram DNA em todas as amostras de sangue extraídas. Em conjunto, os dados da literatura e o deste trabalho sugerem que a técnica utilizada no Protocolo 1 é viável para a extração do DNA e amplificação por PCR. Além disso, Smith et al.,(1996) ao trabalharem com extração de DNA dentro e entre populações de perus e galinhas, verificaram que a tecnologia de extração alcalina rápida de sangue pode ser aplicada com sucesso em diferentes espécies. Os resultados em questão estão de acordo com Bello et al. (2001) que descreveram um protocolo para extração de DNA de penas e obtiveram DNA de boa quantidade e qualidade. Como foi observado no presente estudo, a quantidade e a integridade do DNA isolados, são dois parâmetros que são essenciais para o êxito da otimização de testes de PCR.

Nos dois protocolos alcalinos rápidos utilizados (para sangue e pelo), apesar da impureza relacionada a proteínas e a sais, observada na espectrofotometria, a amplificação pela PCR não foi inibida. Possivelmente, a diluição realizada para adequar a quantidade de DNA, necessária para a amplificação, diminuiu também a concentração de proteínas e sais a níveis baixos, que não foram suficientes para inibir a PCR.

Todas as amostras de sangue extraídas pelo cartão FTA apresentaram DNA amplificado pela PCR confirmando a eficiência do kit Nucleo Spim ${ }^{\circledR}$ para extração de DNA de sangue em FTA Cards (Figura 1). Para realização da PCR foi utilizado diretamente o produto da extração sem diluição. Os resultados encontrados se assemelham aqueles apresentados por Halbert et al. (2009) em que foram extraídas 8 amostras de sangue de animais das raças Hereford e Braford de rebanhos criados no Rio Grande do Sul utilizando cartões FTA. Este resultado indica que o protocolo testado no presente trabalho é adequado para a extração de DNA de amostras de sangue conservadas em cartões FTA.

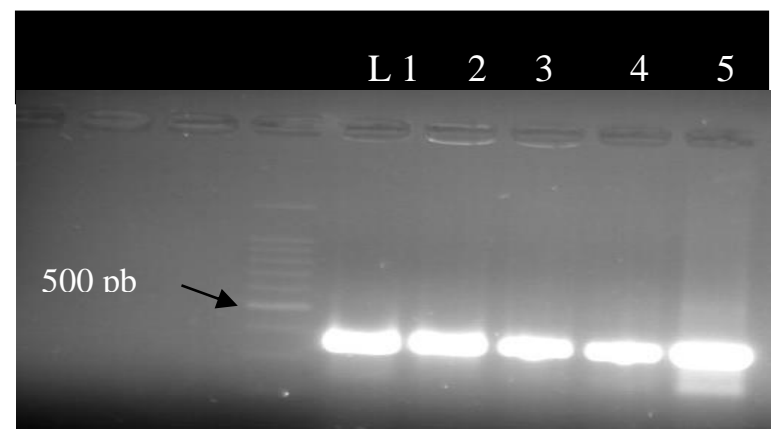

Figura 1. Gel de agarose da amplificação das amostras de sangue armazenadas em cartão FTA.

O custo de cada método foi estimado em reais com base no preço dos reagentes utilizados para a extração do DNA de 50 amostras. Observa-se na Tabela 3, que os protocolos mais baratos para extrair DNA do sangue e penas de aves foi o protocolo 1 e 2 que utilizou a técnica alcalina rápida.

Considerando-se fatores como custo, rapidez e praticidade o melhor protocolo de extração de 
DNA de aves caipiras foi o protocolo 1, que além de extrair boa quantidade de DNA, também teve menor custo.

Tabela 3. Custos de cada protocolo utilizado para extração de DNA de amostras de sangue e pena de galinhas caipiras

\begin{tabular}{lc}
\hline Protocolos & Custo (R $\$ / 50$ amostras) \\
\hline 1 (AR-S) & 0,181 \\
2 (AR-P) & 0,839 \\
3 (FTA-N) & 341,50 \\
\hline 1 (AR-S): Extração Alcalina rápida de DNA \\
utilizando sangue total; 2 (AR-P): Extração alcalina \\
rápida de DNA utilizando pena; 3 (FTA-N): Extração \\
de DNA com Kit comercial NucleoSpin ${ }^{\circledR}$ \\
Tissue/Macherey-Nagel@ (utilizando sangue em FTA \\
Card).
\end{tabular}

Com relação à simplicidade e armazenamento das amostras observou-se que o método de extração do DNA pelas penas é mais simples. A coleta de penas para posterior análise oferece menos riscos ao animal além de ser fácil de ser transportada e haver pouca contaminação.

\section{Conclusão}

Os protocolos alcalinos rápidos usados tanto em sangue quanto em penas foram rápidos e de fácil execução sendo ideal na rotina laboratorial. Recomenda-se o uso de penas para extração de DNA em aves, pois diminui o estresse ao animal no momento da coleta e obtém DNA de boa qualidade e quantidade satisfatórias.

\section{Referências Bibliográficas}

Abreu, R. D.; Vieira Jr., J. R.; Costa, M. Do C. M. M. 2004. Frangos e ovos caipiras: Produção de frangos e ovos. Serviço Nacional de Aprendizagem Rural - SENAR, Brasília/DF. 115p.

Ali, B. A.; Ahmed, M. M. M.; Bahie El-Deen, M.; Shalan, H. M. 2002. Genetic variability in the 17th generation of Japanese quail selected for high eggs and meat production. Egyptian Journal Poultry Science. 22:59-71.

Bartholazzi Junior, A.; Pacheco, A.; Quirino, C. R.; Coelho, E. G. A.; Corrêa, T. S.; Arrais A. M. 2012. Avaliação quantitativa e qualitativa de métodos de extração alcalina do DNA a partir de amostras de sêmen, sangue e pêlos de ovinos (Ovis aries). In: IX Simpósio Brasileiro de Melhoramento Animal, João Pessoa, PB - 20 a 22 de junho de 2012.
Bello, N.; Francino, O.; Sánchez, A. 2001. Isolation of genomic DNA from feathers. Journal of Veterinary Diagnostic Investigation. 13:162-164 (Brief communications).

Boelling, D.; Groen, A. F.; Sorensen, P. et al. 2003. Genetic improvement of livestock for organic farming systems. Livestock Production Science, 80:79-88.

Caldart, E. T.; Chiappetta, C. M.; Lopes, E. F. \& Ravazzolo, A.P. 2011. Análise comparativa de métodos de extração de DNA genômico de celulas do sangue e do leite de pequenos ruminantes. Acta Scientiae Veterinariae, 39:945.

Coelho, E. G. A. Comparação entre métodos de estocagem de DNA extraído de amostras de sangue, sêmen e pêlos e entre técnicas de extração. Tese apresentada como obtenção de título de Mestre e conclusão de curso, Universidade Federal de Minas Gerais, 2001.

Coelho, E. G. A.; Oliveira, D. A. A.; Teixeira, C. S.; Sampaio, I. B. M.; Rodrigues, S. G. \& Alves, C. 2004. Comparação entre métodos de estocagem de DNA extraído de amostras de sangue, sêmen e pêlos e entre técnicas de extração. Arquivos Brasileiros de Medicina Veterinária e Zootecnia, 56:111-115.

Dekkers J. C. M. \& Hospital, F. 2002.The use of molecular genetics in the improvement of agricultural populations. Nature Reviews Genetics, 3:22-32.

Fungaro, M. H. P. \& Vieira, M. L. C. 2001. Marcadores moleculares. In: Serafini Gagneux, P., Boesch, C. \& Woodruff, D.S. 1997. Microsatellite scoring errors associated with noninvasive genotyping based on nuclear DNA amplified from shed hair. Molecular Ecology, 6:861-868.

Halbert, N.; Iverson, B.; Dell'orco, R. \& Cohen, L. 2009. Recovery of DNA from a filter paper matrix for high-throughput genotyping. GenVault Corporation, Carlsbad, California. 2009.

Manual Nano Drop. 2010. Thermo Scientific Nano Drop Spectrophotometers Nucleic Acid. $30 \mathrm{p}$.

Santana Filho, E. P. \& Lima, D.J. 2012. Criação de aves semiconfinadas. Ilhéus, Ceplac/ Cenex. 48p. 
Savino, V. J. M.; Coelho, A. A. D.; Rosário, M. F. \& Silva, M. A. N. 2007. Avaliação de materiais genéticos visando à produção de frango caipira em diferentes sistemas de alimentação. Revista Brasileira de Zootecnia, 36:578-583.

SAS. 2009. Statistical Analysis System software release 9.1. SAS Institute Inc., Cary, NC.

Sharma, D.; Appa Rao, K. B. C. \& Totey, S. M. 2000.Measurement of within and between population genetic variability in quails. British Poultry Science, 41:29-32.

Silva, N. M. A.; Araújo, R. O.; Lacerda, T. S. A. Gomes, C. C. G. Cardoso F. F. et al. 2012. Aprimoramento de protocolos de extração de DNA de sangue armazenado em cartões FTA. Anais da $49^{a}$ Reunião Anual da Sociedade Brasileira de Zootecnia - A produção animal no mundo em transformação Brasília - DF, 23 a 26 de Julho de 2012.

Smith, J. C. P. \& Bartlett J, N. K. E. 1996. Use of randomly amplified polymorphic DNA markers for the genetic analysis of relatedness and diversity in chickens and turkeys. Poult. Sci., 75:579-584.
Vieira, J. N.; Coelho, E. G. A. \& Oliveira, D. A. A. 2010. Comparação de três técnicas de extração de DNA para sexagem molecular em aves. Veterinária e Zootecnia, 17:394-398.

Takahashi, S.E. 2003. Efeito do sistema de criação sobre o desempenho e a qualidade de carne de frangos de corte tipo colonial e industrial. Botucatu: Universidade Estadual Paulista, 2003. 64p. Dissertação (Mestrado em Nutrição e Produção Animal) - Universidade Estadual Paulista.

\section{Recebido em Julho 28, 2015}

Aceito em Setembro 9, 2015

License information: This is an open-access article distributed under the terms of the Creative Commons Attribution License, which permits unrestricted use, distribution, and reproduction in any medium, provided the original work is properly cited. 